\title{
Modulatory effects of bestatin on $T$ and $B$ lymphocyte subsets and the concentration of cytokines released by Th1/Th2 lymphocytes in cyclophosphamide-treated mice
}

\author{
MAGDALENA LIS, BOŻENA OBMIŃSKA-MRUKOWICZ
}

Department of Biochemistry, Pharmacology and Toxicology, Faculty of Veterinary Medicine, Wrocław University of Environmental and Life Sciences, Poland

\begin{abstract}
The low-molecular weight dipeptide bestatin is a potent inhibitor of aminopeptidase $N$ and has been demonstrated to have antitumor and immunomodulatory action. The effects of bestatin on the total number of lymphocytes in the thymus, spleen and mesenteric lymph nodes, and the percentage and the absolute count of $T$ cell subsets $(C D 4+C D 8+, C D 4-C D 8-, C D 4+, C D 8+)$ in the thymus and $T(C D 3+$, $\mathrm{CD} 4+, C D 8+)$ and $\mathrm{B}(\mathrm{CD} 19+)$ lymphocytes in the spleen and mesenteric lymph nodes, as well as the production of cytokines by Th1/Th2 lymphocytes were studied in cyclophosphamide-immunocompromised mice. Bestatin was administered at doses of 1 and $0.1 \mathrm{mg} / \mathrm{kg}$ five times at $48 \mathrm{~h}$ intervals or ten times at $24 \mathrm{~h}$ intervals, intraperitoneally. Immunosuppression was induced by a single injection of cyclophosphamide at a dose of $350 \mathrm{mg} / \mathrm{kg}$. It was found that bestatin administered ten times at $24 \mathrm{~h}$ intervals at a dose of $1 \mathrm{mg} / \mathrm{kg}$ increased the total number of splenic lymphocytes (which was previously decreased by cyclophosphamide). Five and ten exposures to the investigated doses enhanced the suppressive effect of cyclophosphamide on the percentage and the absolute count of B lymphocytes in the spleen and mesenteric lymph nodes. However, the drug increased the percentage and the absolute count of T lymphocytes CD3+ with concomitant increase in both subpopulations of T lymphocytes CD4+ and CD8+ in peripheral lymphatic organs of cyclophosphamide-immunocompromised mice. This immunocorrecting effect of bestatin depended on the dosage and the number of subsequent doses applied. Bestatin decreased the concentration of interleukin 2 (IL-2), interferon $\gamma(I F N-\gamma)$ and tumor necrosis factor $\alpha(T N F-\alpha)$ (which was previously increased by cyclophosphamide), irrespective of the dosage and the number of subsequent doses applied.
\end{abstract}

Key words: bestatin, cyclophosphamide, lymphocytes, cytokines, mice.

(Centr Eur J Immunol 2013; 38 (1): 42-53)

\section{Introduction}

Bestatin (ubenimex) - [(2S, 3R)-3-amino-2-hydroxy-4phenylbutanoyl]-L-leucine [1] - is a biological response modifier [2] isolated from a culture filtrate of Streptomyces olivoreticuli [3]. The drug exerts antitumor [4-6], antiviral [7] antibacterial [8] and antifungal [9] action, by modulating the functions of immune cells. The immunomodulatory action of bestatin on lymphocytes has been reported in earlier studies by the same authors [10]. It has been found that bestatin administered to mice is able to change the per- centage and the absolute count of $\mathrm{T}$ cell subsets in the thymus and $\mathrm{T}$ and $\mathrm{B}$ lymphocytes in the spleen and mesenteric lymph nodes. The results show a relationship between the modulating effect induced by bestatin and the dose of the drug as well as the number of doses applied. The authors indicate that multiple exposures to bestatin at the dose of 1 and $0.1 \mathrm{mg} / \mathrm{kg}$ increased the percentage and absolute count of immature double-positive (CD4+CD8+) thymic cells and decreased the percentage and absolute count of $\mathrm{T}$ CD3+ splenocytes and mesenteric lymph node cells with corresponding decreases in the percentage and absolute

Correspondence: Bożena Obmińska-Mrukowicz, Department of Biochemistry, Pharmacology and Toxicology, Faculty of Veterinary Medicine, Wrocław University of Environmental and Life Sciences, Norwida 31, 50-375 Wrocław, Poland, tel. +48 7132054 32, fax +48 713205455 , e-mail: b.mrukowicz@gmail.com 
count of CD4+ and CD8+ cells. Moreover, both a single and multiple administration of bestatin at the dose of 10,1 and $0.1 \mathrm{mg} / \mathrm{kg}$ augmented the percentage and absolute count of CD19+ (B lymphocytes) in the peripheral lymphatic organs. Lis et al. [11] also reported that bestatin increased the function of B lymphocytes, because administration of the drug at the dose of 10,1 and $0.1 \mathrm{mg} / \mathrm{kg}$ five or ten times to SRBC-immunized mice prior to the antigen potentiated humoral response to SRBC resulting in an increased number of splenocytes producing haemolytic anti-SRBC antibodies (PFC) and the 2-mercaptoethanol resistant serum haemagglutinin titre. The modulating effect of bestatin depended on the dosage and schedule of the mice treatment. Exposure to ten bestatin doses at 24-hour intervals was less activating than five injections. In these study authors also indicate that administration of bestatin after pharmacological immunosuppression induced by injection of cyclophosphamide at a high dose of $350 \mathrm{mg} / \mathrm{kg}$ partially inhibited the suppressive action of the drug in the in vivo model of humoral immune response to SRBC. The protective action of bestatin was dose and schedule dependent. The strongest protective effect was observed after ten times' exposure to bestatin at a dose of $0.1 \mathrm{mg} / \mathrm{kg}$. In this experimental protocol, five times' administration of bestatin at doses of 1 and $0.1 \mathrm{mg} / \mathrm{kg}$ did not reduce, but temporarily intensified the suppressive action of cyclophosphamide on the production of total anti-SRBC haemagglutinins.

The postulated mechanism of immunomodulatory action of bestatin involves aminopeptidase inhibitition, with aminopeptidise N (APN) (EC 3.4.11.2) considered the particular target of the drug $[3,12]$. The enzyme is known under several different names: aminopeptidase $\mathrm{M}$, alanine aminopeptidase, microsomal aminopeptidase, microsomal leucine aminopeptidase, amino oligopeptidase, and GP 150. Aminopeptidise $\mathrm{N}$ is a membrane-bound metalloprotease which is identical with cell surface molecule CD13 [12]. The enzyme is found in two forms - soluble APN (in plas$\mathrm{ma} /$ serum and urine) and the membrane-bound APN $[12,13]$. The membrane-bound APN/CD13 is present in many different cell types such as epithelial and endothelial cells, fibroblasts and hematopoietic cells of myeloid origin. The elevated level of APN/CD13 has been observed in many kinds of tumors and some inflammatory diseases [12]. Therefore, by inhibiting APN/CD13, bestatin exerts positive effects in the therapy of such illnesses [12], which was confirmed in experimental $[14,15]$ and clinical trials $[16,17]$.

On the other hand, the therapy of cancer and many inflammatory diseases involves the use of immunosuppressive drugs. Bestatin, as an immunomodulator, may be able to restore the functions of the immune system, impaired by these immunosuppressants. Cyclophosphamide, an alkylating agent used in cancer treatment and autoimmune diseases, is also used in experimental immunopharmacology to induce immunosuppression and estimate the immuno- correcting action of drugs or substances investigated for their immunomodulatory potential.

The purpose of the present study was to determine the action of bestatin at different dosages and schedules of treatment on the surface marker expression of the thymus, spleen and mesenteric lymph node cells and on the serum concentration of cytokines released by Th1/Th2 lymphocytes in a cyclophosphamide-induced immunosuppressed mouse model.

\section{Material and methods}

\section{Animals}

The studies were conducted on female $\mathrm{Balb} / \mathrm{c}$ mice ( 8 weeks of age), each weighing $20 \mathrm{~g}$. The mice were kept under conventional conditions. The animals were fed a commercial, granulated food and water ad libitum. The experimental animals were obtained from a Breeding Center of Laboratory Animals at the Institute of Occupational Medicine, Łódź, Poland. The principles of laboratory animal care (NIH publication No 86-23, revised 1985) as well as the specific national laws on the protection of animals were followed. The study protocol was approved by the II Local Ethics Committee in Wrocław, Poland (No 08/2008).

\section{Drugs and treatment}

Pharmacological immunosuppression was induced by a single intraperitoneal (i.p.) injection of cyclophosphamide administered at a dose of $350 \mathrm{mg} / \mathrm{kg}$. Bestatin was injected i.p. at doses of 1 and $0.1 \mathrm{mg} / \mathrm{kg}$ to cyclophosphamideimmunosuppressed mice five times at 48-hour intervals or ten times at 24-hour intervals. The first dose of the drug was administered 24 hours after cyclophosphamide injection. Bestatin and cyclophosphamide were dissolved in phosphate buffered saline (PBS). The trials in the control groups were conducted in parallel. The mice in the control groups received PBS instead of bestatin or cyclophosphamide. The volume of each dose of bestatin, cyclophosphamide or PBS was $0.2 \mathrm{ml}$ per animal. Each experimental group consisted of eight mice.

\section{Materials}

Bestatin (in subst., Sigma-Aldrich Chemie GmbH, Riedstr. 2, D-89555 Steiheim, Germany), Rat Anti-Mouse CD4:FITC/CD8:RPE dual color reagent (Serotec, Kidlington, UK), Rat Anti-Mouse CD19:FITC/CD3:RPE dual color reagent (Serotec, Kidlington, UK), Ficoll 400 (Pharmacia, Fine Chemicals AB, Uppsala, Sweden), Urografin 76\% (diatrizoate sodium and meglumine diatrizoate, Bayer Schering Pharma, Poland), $1 \%$ bovine serum albumin (BSA, Sigma), phosphate buffered saline (PBS, Institute of Immunology and Experimental Therapy, Wrocław, Poland), cyclophosphamide (Endoxan, Baxter), BD ${ }^{\mathrm{TM}}$ Cytometric Bead Array Mouse Th1/Th2 Cytokine Kit (CBA) (BD Bio- 
sciences Pharmingen, San Diego, USA), Halothane (Narcotan, Zentiva, Prague, Czech Republic).

\section{Measurements}

The following measurements were taken: 1) the total number of thymocytes, splenocytes and lymphocytes of mesenteric lymph nodes; 2) the weight ratio of thymus, spleen and mesenteric lymph nodes, calculated according to the following formula: weight of an organ $(\mathrm{g}) / \mathrm{body}$ weight of a mouse $(\mathrm{g}) \times 100 ; 3)$ the percentage and count of lymphocyte subpopulations in lymphatic organs; and 4) the serum concentrations of cytokines (IL-2, IL-5, IFN- $\gamma$, TNF- $\alpha$ ) released by Th1/Th2 lymphocytes.

The total number of thymocytes, splenocytes and lymphocytes of mesenteric lymph nodes, the weight ratio of the thymus, spleen and mesenteric lymph nodes, and CD subsets in the thymus, spleen and mesenteric lymph nodes were determined 24 and 72 hours after the last bestatin administration, that is, on days 12 and 14 after injection of cyclophosphamide. The serum concentrations of cytokines released by Th1/Th2 lymphocytes were determined $24 \mathrm{~h}$ after the last dose of bestatin, that is, on day 12 following the exposure to cyclophosphamide.

\section{Assay of thymocyte, splenocyte and lymphocyte of mesenteric lymph node subsets}

Halothane anaesthetized mice were killed by cervical dislocation 24 or 72 hours after the final dose of bestatin. Thymuses, spleens and mesenteric lymph nodes were removed and placed in disposable Petri dishes containing a sterile, icecold PBS. The suspended cells were released from the lymphatic organs by passage through a nylon mesh and then centrifuged $\left(2250 \times \mathrm{g}, 15 \mathrm{~min}, 4^{\circ} \mathrm{C}\right)$ on a layer of Ficoll $400 /$ Urografin $76 \%$ at a $1: 3$ ratio at the density of 1.076 . After centrifugation, the cells were collected from the interphase and washed twice $\left(375 \times \mathrm{g}, 8 \mathrm{~min}, 4^{\circ} \mathrm{C}\right)$ with a sterile, ice-cold PBS supplemented with $1 \%$ BSA. After the second wash, the cells were suspended in PBS with $1 \%$ BSA at $1 \times 10^{7}$ cells $/ \mathrm{ml}$. The viability of each cell suspension was $90-98 \%$, as determined by trypan blue dye-exclusion assay. The cells were resuspended in $100 \mu 1$ PBS solution containing $1 \%$ BSA. The thymocytes, splenocytes and lymphocytes of the mesenteric lymph nodes were stained with Rat AntiMouse CD4:FITC/CD8:RPE dual color reagent at a dilution recommended by the manufacturer. The splenocytes and lymphocytes of the mesenteric lymph nodes were also stained with Rat Anti-Mouse CD19:FITC/CD3: RPE dual color reagent at a dilution recommended by the producer.

The cells were incubated at $4^{\circ} \mathrm{C}$ for $30 \mathrm{~min}$ and washed $\left(375 \times \mathrm{g}, 8 \mathrm{~min}, 4^{\circ} \mathrm{C}\right)$ three times with an ice-cold PBS. The fluorescence was analyzed using a flow cytometer (FACS Calibur; Becton Dickinson Biosciences, San Jose, CA, USA). Data acquisition and analysis were done using a CellQuest 3.1f software. A two-color analysis was performed: fluorescence 1 (FL1) - FITC: emission peak $525 \mathrm{~nm}$, fluo- rescence 2 (FL2) - PE: emission peak $575 \mathrm{~nm}$. Instrument settings used in this study were as follows: FL1: log, $584 \mathrm{~V}$, FL2: $\log , 595 \mathrm{~V}$, the fluorescence compensation: FL1: $-1.7 \%$ FL2; FL2: $-22.3 \%$ FL1. A total of 10000 events were collected.

\section{Determination of the total number of thymocytes, splenocytes and mesenteric lymph node lymphocytes}

The lymphatic organs after removing from anaesthetized with halothane mice were passed through a nylon mesh into $1 \mathrm{ml}$ of a sterile, ice-cold PBS. Next, the suspended cells were diluted ten times in PBS. The number of mononucleated cells from central and peripheral lymphatic organs was counted in a Thoma hemocytometer using Türk solution.

\section{Assay of the serum concentration of cytokines released by Th1/Th2 lymphocytes}

The mice were anaesthetized with halothane. The blood samples were taken from retro-ocular artery. The sera were obtained by blood centrifugation ( $3500 \mathrm{~g}, 15 \mathrm{~min})$. A commercial BD ${ }^{\mathrm{TM}}$ Cytometric Bead Array Mouse Th1/Th2 Cytokine Kit (CBA) was used to determine the levels (pg/ml) of interleukin 2 (IL-2), interferon $\gamma$ (IFN- $\gamma$ ), IL-5 and tumor necrosis factor (TNF) in serum samples, according to the manufacturer's instructions. Fluorescence was analyzed using a flow cytometer (FACS Calibur; Becton Dickinson Biosciences, San Jose, CA, USA) and cytokine level was determined with a BD CBA Software.

\section{Statistical analysis}

The differences between the groups were assessed using the one-way analysis of variance (ANOVA) and post hoc analysis with Scheffé test using STATISTICA 9.1 software. A $p$ value of $<0.05$ was considered significant.

\section{Results}

The effects of bestatin on the total number of lymphocytes in the thymus, spleen and mesenteric lymph nodes and the weight ratio of lymphatic organs in cyclophosphamide - treated mice

A single administration of cyclophosphamide at a dose of $350 \mathrm{mg} / \mathrm{kg}$ decreased the total number of lymphocytes in the thymus, spleen and mesenteric lymph nodes on days 12 and 14 following the exposure to the drug. The administration of cyclophosphamide also decreased the weight ratio of thymus and mesenteric lymph nodes but increased the weight ratio of spleen (Tables 1 and 2). As can be seen in Table 1, administration of bestatin at doses of 1 or $0.1 \mathrm{mg} / \mathrm{kg}$ five times on alternating days did not change the effect of cyclophosphamide on the total number of lymphocytes in the thymus, spleen and mesenteric lymph nodes, and the weight ratio of thymus and mesenteric lymph nodes. However, it increased (in comparison to the control group) 
Table 1. The effects of bestatin (BE) administered five times on alternating days on the total number of thymocytes, splenocytes and mesenteric lymph nodes cells and on weight ratio of thymus, spleen and mesenteric lymph nodes in cyclophosphamide (CY)-treated mice. The mean values $(n=8)$ and standard deviations are presented

\begin{tabular}{|c|c|c|c|c|c|}
\hline Index & Hour & PBS & $\mathrm{CY}+\mathrm{PBS}$ & $\begin{array}{c}\mathrm{CY}+\mathrm{BE} \\
5 \times 1 \mathrm{mg} / \mathrm{kg}\end{array}$ & $\begin{array}{c}\mathrm{CY}+\mathrm{BE} \\
5 \times 0.1 \mathrm{mg} / \mathrm{kg}\end{array}$ \\
\hline \multirow{2}{*}{$\begin{array}{l}\text { The total number of } \\
\text { thymocytes }\left(\times 10^{6}\right)\end{array}$} & 24 & $30.1 \pm 4.8^{\mathrm{a}}$ & $7.5 \pm 3.9^{b}$ & $10.3 \pm 5.1^{\mathrm{b}}$ & $11.8 \pm 5.2^{\mathrm{b}}$ \\
\hline & 72 & $29.9 \pm 4.0^{\mathrm{a}}$ & $6.9 \pm 2.4 b$ & $10.5 \pm 5.6^{b}$ & $8.0 \pm 3.6^{b}$ \\
\hline \multirow[t]{2}{*}{ Weight ratio of thymus } & 24 & $0.188 \pm 0.04^{\mathrm{a}}$ & $0.064 \pm 0.019^{b}$ & $0.082 \pm 0.032^{\mathrm{b}}$ & $0.088 \pm 0.025^{\mathrm{b}}$ \\
\hline & 72 & $0.185 \pm 0.04^{\mathrm{a}}$ & $0.084 \pm 0.041^{\mathrm{b}}$ & $0.093 \pm 0.024^{b}$ & $0.087 \pm 0.028^{b}$ \\
\hline \multirow{2}{*}{$\begin{array}{l}\text { The total number of } \\
\text { splenocytes }\left(\times 10^{6}\right)\end{array}$} & 24 & $68.3 \pm 9.6^{\mathrm{a}}$ & $40.6 \pm 20.2^{b}$ & $35.3 \pm 7.9^{b}$ & $40.6 \pm 15.9^{b}$ \\
\hline & 72 & $71.9 \pm 9.8^{\mathrm{a}}$ & $36.0 \pm 15.9^{b}$ & $46.2 \pm 14.7 \mathrm{~b}$ & $50.0 \pm 11.4^{b}$ \\
\hline \multirow[t]{2}{*}{ Weight ratio of spleen } & 24 & $0.621 \pm 0.075$ & $0.856 \pm 0.273$ & $0.92 \pm 0.3$ & $0.852 \pm .334$ \\
\hline & 72 & $0.575 \pm 0.13^{\mathrm{b}}$ & $0.836 \pm 0.232^{\mathrm{a}, \mathrm{b}}$ & $1.054 \pm 0.332^{\mathrm{a}}$ & $1.055 \pm 0.377^{\mathrm{a}}$ \\
\hline \multirow{2}{*}{$\begin{array}{l}\text { The total number of mesenteric } \\
\text { lymph nodes cells }\left(\times 10^{6}\right)\end{array}$} & 24 & $33.0 \pm 3.4^{\mathrm{a}}$ & $13.3 \pm 6.8^{\mathrm{b}}$ & $15.4 \pm 7.7^{b}$ & $12.1 \pm 2.1^{\mathrm{b}}$ \\
\hline & 72 & $29.4 \pm 5.9^{\mathrm{a}}$ & $11.1 \pm 3.2^{\mathrm{b}}$ & $11.1 \pm 4.5^{\mathrm{b}}$ & $13.7 \pm 4.3^{\mathrm{b}}$ \\
\hline \multirow{2}{*}{$\begin{array}{l}\text { Weight ratio of mesenteric } \\
\text { lymph nodes }\end{array}$} & 24 & $0.377 \pm 0.08$ & $0.27 \pm 0.04$ & $0.329 \pm 0.099$ & $0.29 \pm 0.071$ \\
\hline & 72 & $0.406 \pm 0.07^{\mathrm{a}}$ & $0.291 \pm 0.061^{\mathrm{b}}$ & $0.298 \pm 0.026^{b}$ & $0.285 \pm 0.041^{b}$ \\
\hline
\end{tabular}

Data with the different letter in the superscript show significant difference $(p<0.05)$

Table 2. The effects of bestatin (BE) administered ten times at $24 \mathrm{~h}$ intervals on the total number of thymocytes, splenocytes and mesenteric lymph nodes cells and on weight ratio of thymus, spleen and mesenteric lymph nodes in cyclophosphamide (CY)-treated mice. The mean values $(n=8)$ and standard deviations are presented

\begin{tabular}{|c|c|c|c|c|c|}
\hline Index & Hour & PBS & $\mathrm{CY}+\mathrm{PBS}$ & $\begin{array}{c}\mathrm{CY}+\mathrm{BE} \\
10 \times 1 \mathrm{mg} / \mathrm{kg}\end{array}$ & $\begin{array}{c}\mathrm{CY}+\mathrm{BE} \\
10 \times 0.1 \mathrm{mg} / \mathrm{kg} \\
\end{array}$ \\
\hline \multirow{2}{*}{$\begin{array}{l}\text { The total number of } \\
\text { thymocytes }\left(\times 10^{6}\right)\end{array}$} & 24 & $29.5 \pm 7.5^{\mathrm{a}}$ & $9.3 \pm 2.4^{b}$ & $10.9 \pm 3.5^{\mathrm{b}}$ & $8.1 \pm 2.6^{\mathrm{b}}$ \\
\hline & 72 & $28.5 \pm 6.9^{\mathrm{a}}$ & $18.0 \pm 4.7^{\mathrm{b}}$ & $21.4 \pm 9.1^{\mathrm{a}, \mathrm{b}}$ & $23.7 \pm 4.7^{\mathrm{a}, \mathrm{b}}$ \\
\hline \multirow[t]{2}{*}{ Weight ratio of thymus } & 24 & $0.147 \pm 0.033^{\mathrm{a}}$ & $0.048 \pm 0.013^{b}$ & $0.063 \pm 0.02^{\mathrm{b}}$ & $0.058 \pm 0.021^{b}$ \\
\hline & 72 & $0.189 \pm 0.041^{\mathrm{a}}$ & $0.131 \pm 0.025^{b}$ & $0.115 \pm 0.035^{b}$ & $0.13 \pm 0.031^{b}$ \\
\hline \multirow{2}{*}{$\begin{array}{l}\text { The total number of } \\
\text { splenocytes }\left(\times 10^{6}\right)\end{array}$} & 24 & $54.2 \pm 9.9^{\mathrm{a}}$ & $33.8 \pm 10.8^{\mathrm{b}}$ & $30.0 \pm 13.1^{\mathrm{b}}$ & $38.5 \pm 6.4^{\mathrm{b}}$ \\
\hline & 72 & $61.7 \pm 6.8^{\mathrm{a}}$ & $47.0 \pm 10.7^{b}$ & $60.0 \pm 5.5^{\mathrm{a}}$ & $56.3 \pm 8.8^{\mathrm{a}, \mathrm{b}}$ \\
\hline \multirow[t]{2}{*}{ Weight ratio of spleen } & 24 & $0.511 \pm 0.062^{b}$ & $0.838 \pm 0.239^{\mathrm{a}}$ & $0.719 \pm 0.25^{\mathrm{a}, \mathrm{b}}$ & $0.733 \pm 0.155^{\mathrm{a}, \mathrm{b}}$ \\
\hline & 72 & $0.739 \pm 0.117^{\mathrm{c}}$ & $1.306 \pm 0.203^{\mathrm{a}}$ & $1.041 \pm 0.124^{\mathrm{b}}$ & $1.02 \pm 0.104^{\mathrm{b}}$ \\
\hline \multirow{2}{*}{$\begin{array}{l}\text { The total number of mesenteric } \\
\text { lymph nodes cells }\left(\times 10^{6}\right)\end{array}$} & 24 & $32.1 \pm 7.3^{\mathrm{a}}$ & $15.0 \pm 6.2^{\mathrm{b}}$ & $17.9 \pm 5.8^{\mathrm{b}}$ & $18.7 \pm 4.1^{\mathrm{b}}$ \\
\hline & 72 & $34.9 \pm 4.4^{\mathrm{a}}$ & $14.1 \pm 4.9^{\mathrm{b}}$ & $18.9 \pm 4.3^{\mathrm{b}}$ & $20.7 \pm 5.1^{\mathrm{b}}$ \\
\hline \multirow{2}{*}{$\begin{array}{l}\text { Weight ratio of mesenteric } \\
\text { lymph nodes }\end{array}$} & 24 & $0.386 \pm 0.044^{\mathrm{a}}$ & $0.319 \pm 0.064^{\mathrm{a}, \mathrm{b}}$ & $0.242 \pm 0.06^{\mathrm{b}}$ & $0.291 \pm 0.069^{\mathrm{b}}$ \\
\hline & 72 & $0.49 \pm 0.085$ & $0.479 \pm 0.15$ & $0.382 \pm 0.074$ & $0.373 \pm 0.051$ \\
\hline
\end{tabular}

Data with the different letter in the superscript show significant difference $(p<0.05)$

the weight ratio of spleen on day 14 following the exposure to the cyclophosphamide.

Ten subsequent administrations of bestatin $(0.1$ and $1 \mathrm{mg} / \mathrm{kg}$ ) at $24 \mathrm{~h}$ intervals did not exert any immunocorrecting action on the total number of thymocytes and lym- phocytes of mesenteric lymph nodes and the weight ratio of thymus in cyclophosphamide-treated mice. However, ten administrations of bestatin at a dose of $1 \mathrm{mg} / \mathrm{kg}$ significantly increased the total number of lymphocytes in spleen and decreased the weight ratio of the organ $72 \mathrm{~h}$ after the injec- 
tion of cyclophosphamide. A decrease of the weight ratio of mesenteric lymph nodes was observed after ten exposures to bestatin at doses of 1 and $0.1 \mathrm{mg} / \mathrm{kg}$ on day 12 following the administration of immunosuppressant (Table 2).

\section{The effects of bestatin on the percentage and the absolute count of lymphocyte subpopulations in the thymus in cyclophosphamide-immunosuppressed mice}

It was found that a single administration of cyclophosphamide at a dose of $350 \mathrm{mg} / \mathrm{kg}$ caused a significant decrease in the total number of thymocytes and in the absolute count of immature CD4+CD8+ (double-positive cells), CD4-CD8- (double-negative cells) and single-positive, mature CD4+ and CD8+ thymic cells on days 12 and 14 after injection (Table 3). Irrespective of the dosage and the number of subsequent doses applied, bestatin did not change the inhibitory action of cyclophosphamide on the total number of thymocytes and the absolute count of CD4+CD8+, CD4-CD8-, CD4+ and CD8+ thymic cells. However, the drug exerted a modulating effect on the percentage of $T$ cell subsets. As can be seen in Table 3 , five exposures to bestatin at a dose of $1 \mathrm{mg} / \mathrm{kg}$ decreased the percentage of CD4+CD8+ thymic cells but increased the percentage of CD4+ and CD8+ thymocytes on day 14 after cyclophosphamide injection. However, bestatin administered five times at $0.1 \mathrm{mg} / \mathrm{kg}$ increased the percentage of CD4-CD8- on day 14 after cyclophosphamide treatment and decreased the percentage of CD4+ and CD8+ thymocytes on day 12 after the administration of this immunosuppressant. Ten subsequent administrations of bestatin at $24 \mathrm{~h}$ intervals at doses of 1 and $0.1 \mathrm{mg} / \mathrm{kg}$ caused a decrease in the percentage of CD4+CD8+ thymocytes with a corresponding increase in the percentage of CD4+ lymphocytes of thymus on day 12 after the injection of cyclophosphamide (Table 3).

\section{The effects of bestatin on the percentage and the absolute count of lymphocyte subpopulations in the spleen in cyclophosphamide - treated mice}

A single administration of cyclophosphamide at a dose of $350 \mathrm{mg} / \mathrm{kg}$ decreased, the total number of lymphocytes in spleen on days 12 and 14 after injection of this drug. Cyclophosphamide significantly reduced the percentage of CD19+ cells (B lymphocytes) in spleen, which caused over a double decrease in the absolute count of lymphocytes B in this organ. However, the percentage of $\mathrm{T}$ lymphocytes CD3+, CD4+, CD8+ in the spleen increased after cyclophosphamide treatment (Table 4). As can be seen in Table 4, bestatin administered five or ten times at all investigated doses augmented the inhibitory action of cyclophosphamide on the percentage and count of B cells in the spleen. Irrespective of the dosage and number of subsequent doses applied, the drug did not restore the cyclophosphamide-suppressed absolute count of CD19+ cells and caused even further decrease in the absolute number of these cells (five injections of bestatin at 1 and $0.1 \mathrm{mg} / \mathrm{kg}$ on day 12 after immunosupression and ten administrations of bestatin at $1 \mathrm{mg} / \mathrm{kg}$ on day 14 after exposure to cyclophosphamide) (Table 4). On the other hand, the percentage of CD3+ and CD4+ T splenocytes of cyclophosphamide-treated mice increased after bestatin treatment. The modulating effect of bestatin on splenic T lymphocytes depended primarily on the number of doses applied and, to a lesser extent, on the dosage of the drug. The strongest stimulating effect of bestatin on the percentage of $\mathrm{T}$ splenocytes was observed after ten bestatin injections at 1 and $0.1 \mathrm{mg} / \mathrm{kg}$ doses, on days 12 and 14 after immunosuppression (Table 4). At the same time, the absolute count of T cells in the spleen also increased. Exposure to five doses of bestatin was less activating than ten injections. An increase in the percentage of CD3+ cells was observed after five exposures to bestatin at doses of 1 and $0.1 \mathrm{mg} / \mathrm{kg}$ only on day 12 after immunosuppression, whereas an increase in the percentage of CD4+ splenocytes was observed only after $0.1 \mathrm{mg} / \mathrm{kg}$ of bestatin administered five times (determined on the same day). Bestatin administered five times at a dose of $0.1 \mathrm{mg} / \mathrm{kg}$ also increased the percentage and the absolute count of CD8+ lymphocytes of spleen on day 14 after immunosuppression.

The effects of bestatin on the percentage and the absolute count of lymphocyte subpopulations in the mesenteric lymph nodes in cyclophosphamide - treated mice

On days 12 and 14 after injection, a single administration of cyclophosphamide at a dose of $350 \mathrm{mg} / \mathrm{kg}$ caused a decrease in the total number of lymphocytes in mesenteric lymph nodes. Cyclophosphamide significantly reduced the percentage of CD19+ cells (B lymphocytes) in mesenteric lymph nodes, which caused more than three times decrease in the absolute count of lymphocytes B in that tissue (Table 5). Even though the percentage of T CD3+, CD4+, CD8+ lymphocytes in mesenteric lymph nodes increased after cyclophosphamide injection, the absolute count of these cells decreased due to the fall in the total number of lymphocytes in these organs. As can be seen in Table 5, irrespective of the dosage and number of subsequent doses applied, bestatin enhanced the inhibitory action of cyclophosphamide on the percentage of B lymphocytes in mesenteric lymph nodes. Bestatin did not prevent the suppressive action of cyclophosphamide on the absolute number of CD19+ cells. Moreover, a further decrease was observed when bestatin was administered ten times at a dose of $0.1 \mathrm{mg} / \mathrm{kg}$ (Table 5). However, the percentage of T CD3+, CD4+ and CD8+ lymphocytes of mesenteric lymph nodes in cyclophosphamide-treated mice increased after bestatin administration (Table 5). The stimulating effect of bestatin on T lymphocytes depended on the number of doses applied as well as the drug's dosage. Bestatin exerted the strongest 
Table 3. The percentage and absolute count of thymocytes subpopulations in cyclophosphamide (CY)-treated mice after administration of bestatin $(\mathrm{BE})$ five times on alternating days or ten times at $24 \mathrm{~h}$ intervals. The mean values $(n=8)$ and standard deviations are presented

\begin{tabular}{|c|c|c|c|c|c|c|}
\hline Index & & Hour & PBS & $\mathrm{CY}+\mathrm{PBS}$ & $\begin{array}{c}\mathrm{CY}+\mathrm{BE} \\
5 \times 1 \mathrm{mg} / \mathrm{kg}\end{array}$ & $\begin{array}{c}\mathrm{CY}+\mathrm{BE} \\
5 \times 0.1 \mathrm{mg} / \mathrm{kg}\end{array}$ \\
\hline \multicolumn{7}{|l|}{ Thymocytes } \\
\hline \multirow[t]{4}{*}{ CD4-CD8- } & $(\%)$ & 24 & $1.9 \pm 0.8$ & $2.0 \pm 1.0$ & $2.5 \pm 1.5$ & $1.7 \pm 0.7$ \\
\hline & $\left(\times 10^{6}\right)$ & & $0.6 \pm 0.2^{\mathrm{a}}$ & $0.2 \pm 0.1^{\mathrm{b}}$ & $0.2 \pm 0.1^{b}$ & $0.2 \pm 0.1^{b}$ \\
\hline & $(\%)$ & 72 & $1.8 \pm 0.5^{b}$ & $2.7 \pm 0.8^{\mathrm{a}, \mathrm{b}}$ & $3.1 \pm 1.4^{\mathrm{a}, \mathrm{b}}$ & $3.8 \pm 0.8^{\mathrm{a}}$ \\
\hline & $\left(\times 10^{6}\right)$ & & $0.5 \pm 0.2^{\mathrm{a}}$ & $0.2 \pm 0.05^{\mathrm{b}}$ & $0.3 \pm 0.2^{b}$ & $0.3 \pm 0.1^{b}$ \\
\hline \multirow[t]{4}{*}{ CD4+CD8+ } & $(\%)$ & 24 & $79.4 \pm 2.9$ & $80.8 \pm 3.7$ & $79.0 \pm 4.6$ & $83.7 \pm 2.4$ \\
\hline & $\left(\times 10^{6}\right)$ & & $23.9 \pm 3.6^{\mathrm{a}}$ & $6.7 \pm 3.2^{b}$ & $7.7 \pm 4.4^{b}$ & $9.9 \pm 4.5^{\mathrm{b}}$ \\
\hline & $(\%)$ & 72 & $81.2 \pm 1.7^{\mathrm{a}}$ & $76.0 \pm 5.2^{\mathrm{a}, \mathrm{b}}$ & $73.2 \pm 4.2^{\mathrm{b}}$ & $75.3 \pm 4.6^{\mathrm{a}, \mathrm{b}}$ \\
\hline & $\left(\times 10^{6}\right)$ & & $24.3 \pm 3.0^{\mathrm{a}}$ & $5.3 \pm 2.1^{b}$ & $7.8 \pm 4.5^{\mathrm{b}}$ & $6.1 \pm 3.0^{\mathrm{b}}$ \\
\hline \multirow[t]{4}{*}{ CD4+ } & $(\%)$ & 24 & $16.1 \pm 1.5^{\mathrm{a}}$ & $13.9 \pm 2.1^{\mathrm{a}, \mathrm{b}}$ & $16.0 \pm 2.0^{\mathrm{a}, \mathrm{b}}$ & $13.3 \pm 1.6^{\mathrm{b}}$ \\
\hline & $\left(\times 10^{6}\right)$ & & $4.9 \pm 1.1^{\mathrm{a}}$ & $1.0 \pm 0.5^{b}$ & $1.5 \pm 0.7 \mathrm{~b}$ & $1.5 \pm 0.6^{b}$ \\
\hline & $(\%)$ & 72 & $14.5 \pm 1.5^{\mathrm{b}}$ & $17.3 \pm 2.3^{\mathrm{a}, \mathrm{b}}$ & $20.0 \pm 3.0^{\mathrm{a}}$ & $17.3 \pm 3.6^{\mathrm{a}, \mathrm{b}}$ \\
\hline & $\left(\times 10^{6}\right)$ & & $4.4 \pm 0.9^{\mathrm{a}}$ & $1.2 \pm 0.4^{b}$ & $2.0 \pm 0.9^{b}$ & $1.3 \pm 0.5^{b}$ \\
\hline \multirow[t]{4}{*}{ CD8+ } & $(\%)$ & 24 & $2.1 \pm 0.3^{\mathrm{a}}$ & $1.9 \pm 0.2^{\mathrm{a}}$ & $1.7 \pm 0.6^{\mathrm{a}, \mathrm{b}}$ & $1.2 \pm 0.4^{b}$ \\
\hline & $\left(\times 10^{6}\right)$ & & $0.6 \pm 0.1^{\mathrm{a}}$ & $0.1 \pm 0.1^{\mathrm{b}}$ & $0.2 \pm 0.05^{b}$ & $0.1 \pm 0.04^{\mathrm{b}}$ \\
\hline & $(\%)$ & 72 & $2.4 \pm 0.5^{b}$ & $3.1 \pm 1.1^{\mathrm{a}, \mathrm{b}}$ & $3.7 \pm 0.8^{\mathrm{a}}$ & $3.1 \pm 0.3^{\mathrm{a}, \mathrm{b}}$ \\
\hline & $\left(\times 10^{6}\right)$ & & $0.7 \pm 0.2^{\mathrm{a}}$ & $0.2 \pm 0.04^{b}$ & $0.4 \pm 0.2^{b}$ & $0.3 \pm 0.1^{b}$ \\
\hline Index & & Hour & Control (PBS) & $\mathrm{CY}+\mathrm{PBS}$ & $\begin{array}{c}\mathrm{CY}+\mathrm{BE} \\
10 \times 1 \mathrm{mg} / \mathrm{kg}\end{array}$ & $\begin{array}{c}\mathrm{CY}+\mathrm{BE} \\
10 \times 0.1 \mathrm{mg} / \mathrm{kg}\end{array}$ \\
\hline \multicolumn{7}{|l|}{ Thymocytes } \\
\hline \multirow[t]{4}{*}{ CD4-CD8- } & $(\%)$ & 24 & $3.2 \pm 1.0$ & $6.6 \pm 3.2$ & $5.9 \pm 2.8$ & $6.4 \pm 3.1$ \\
\hline & $\left(\times 10^{6}\right)$ & & $1.0 \pm 0.2^{\mathrm{a}}$ & $0.6 \pm 0.4^{\mathrm{a}, \mathrm{b}}$ & $0.5 \pm 0.1^{b}$ & $0.5 \pm 0.4^{b}$ \\
\hline & $(\%)$ & 72 & $6.0 \pm 2.2$ & $5.9 \pm 1.3$ & $5.0 \pm 0.9$ & $4.2 \pm 2.2$ \\
\hline & $\left(\times 10^{6}\right)$ & & $1.7 \pm 0.6^{\mathrm{a}}$ & $1.0 \pm 0.3^{\mathrm{a}, \mathrm{b}}$ & $1.0 \pm 0.4^{\mathrm{a}, \mathrm{b}}$ & $1.0 \pm 0.5^{\mathrm{b}}$ \\
\hline \multirow[t]{4}{*}{$\mathrm{CD} 4+\mathrm{CD} 8+$} & $(\%)$ & 24 & $77.9 \pm 3.9^{\mathrm{a}}$ & $70.4 \pm 8.3^{\mathrm{a}, \mathrm{b}}$ & $66.5 \pm 5.4^{\mathrm{b}}$ & $65.8 \pm 8.9^{\mathrm{b}}$ \\
\hline & $\left(\times 10^{6}\right)$ & & $23.0 \pm 6.2^{\mathrm{a}}$ & $6.5 \pm 1.7 \mathrm{~b}$ & $7.1 \pm 1.7 \mathrm{~b}$ & $5.3 \pm 1.9 \mathrm{~b}$ \\
\hline & $(\%)$ & 72 & $66.0 \pm 3.1$ & $64.6 \pm 4.6$ & $69.9 \pm 3.5$ & $63.8 \pm 9.5$ \\
\hline & $\left(\times 10^{6}\right)$ & & $19.1 \pm 4.3$ & $11.8 \pm 3.2$ & $15.0 \pm 6.6$ & $15.3 \pm 4.6$ \\
\hline \multirow[t]{4}{*}{ CD4+ } & $(\%)$ & 24 & $15.9 \pm 2.5^{\mathrm{b}}$ & $19.2 \pm 4.7^{\mathrm{a}, \mathrm{b}}$ & $23.6 \pm 3.7^{\mathrm{a}}$ & $24.0 \pm 5.0^{\mathrm{a}}$ \\
\hline & $\left(\times 10^{6}\right)$ & & $4.7 \pm 1.2^{\mathrm{a}}$ & $1.8 \pm 0.7^{b}$ & $2.7 \pm 1.2^{\mathrm{b}}$ & $1.9 \pm 0.6^{b}$ \\
\hline & $(\%)$ & 72 & $25.2 \pm 2.2$ & $25.5 \pm 2.5$ & $21.7 \pm 2.8$ & $27.2 \pm 6.6$ \\
\hline & $\left(\times 10^{6}\right)$ & & $7.3 \pm 2.2$ & $4.5 \pm 1.3$ & $4.7 \pm 2.2$ & $6.3 \pm 1.4$ \\
\hline \multirow[t]{4}{*}{ CD8+ } & $(\%)$ & 24 & $2.9 \pm 0.5$ & $3.7 \pm 1.0$ & $3.9 \pm 0.9$ & $3.8 \pm 2.0$ \\
\hline & $\left(\times 10^{6}\right)$ & & $0.9 \pm 0.3^{\mathrm{a}}$ & $0.3 \pm 0.1^{b}$ & $0.4 \pm 0.2^{b}$ & $0.3 \pm 0.1^{b}$ \\
\hline & $(\%)$ & 72 & $3.5 \pm 0.4$ & $3.9 \pm 1.2$ & $3.4 \pm 0.9$ & $3.7 \pm 1.0$ \\
\hline & $\left(\times 10^{6}\right)$ & & $1.0 \pm 0.3$ & $0.7 \pm 0.2$ & $0.7 \pm 0.2$ & $0.9 \pm 0.2$ \\
\hline
\end{tabular}

Data with the different letter in the superscript show significant difference $(p<0.05)$ 
Table 4. The percentage and absolute count of splenocytes subpopulations in cyclophosphamide (CY)-treated mice after administration of bestatin (BE) five times on alternating days or ten times at $24 \mathrm{~h}$ intervals. The mean values $(n=8)$ and standard deviations are presented

\begin{tabular}{|c|c|c|c|c|c|c|}
\hline \multicolumn{2}{|l|}{ Index } & Hour & PBS & CY + PBS & $\begin{array}{c}\mathrm{CY}+\mathrm{BE} \\
5 \times 1 \mathrm{mg} / \mathrm{kg} \\
\end{array}$ & $\begin{array}{c}\mathrm{CY}+\mathrm{BE} \\
5 \times 0.1 \mathrm{mg} / \mathrm{kg}\end{array}$ \\
\hline \multicolumn{7}{|c|}{ Splenocytes } \\
\hline \multirow[t]{4}{*}{ CD3+ } & $(\%)$ & 24 & $35.0 \pm 4.0^{\mathrm{c}}$ & $54.8 \pm 8.9 \mathrm{~b}$ & $73.4 \pm 5.4^{a}$ & $75.6 \pm 5.5^{\mathrm{a}}$ \\
\hline & $\left(\times 10^{6}\right)$ & & $24.1 \pm 5.1$ & $21.2 \pm 8.9$ & $25.8 \pm 5.3$ & $30.2 \pm 10.7$ \\
\hline & $(\%)$ & 72 & $34.1 \pm 4.5^{\mathrm{b}}$ & $48.8 \pm 3.8^{a}$ & $51.7 \pm 8.6^{\mathrm{a}}$ & $51.3 \pm 5.8^{\mathrm{a}}$ \\
\hline & $\left(\times 10^{6}\right)$ & & $24.8 \pm 6.0$ & $17.3 \pm 7.1$ & $23.9 \pm 8.6$ & $25.9 \pm 7.6$ \\
\hline \multirow[t]{4}{*}{ CD4+ } & $(\%)$ & 24 & $28.2 \pm 3.5^{\mathrm{c}}$ & $43.2 \pm 7.9^{b}$ & $50.7 \pm 6.9^{\mathrm{a}, \mathrm{b}}$ & $54.1 \pm 6.1^{\mathrm{a}}$ \\
\hline & $\left(\times 10^{6}\right)$ & & $19.5 \pm 4.6$ & $16.9 \pm 7.9$ & $17.7 \pm 4.1$ & $21.7 \pm 7.7$ \\
\hline & $(\%)$ & 72 & $22.8 \pm 3.5^{\mathrm{b}}$ & $37.7 \pm 6.8^{\mathrm{a}}$ & $46.2 \pm 6.0^{\mathrm{a}}$ & $42.8 \pm 6.1^{\mathrm{a}}$ \\
\hline & $\left(\times 10^{6}\right)$ & & $16.6 \pm 4.4$ & $13.5 \pm 6.2$ & $21.3 \pm 7.4$ & $21.7 \pm 7.1$ \\
\hline \multirow[t]{4}{*}{ CD8+ } & $(\%)$ & 24 & $4.4 \pm 0.8^{b}$ & $8.0 \pm 2.0^{\mathrm{a}}$ & $7.6 \pm 2.0^{\mathrm{a}}$ & $8.6 \pm 1.6^{\mathrm{a}}$ \\
\hline & $\left(\times 10^{6}\right)$ & & $3.0 \pm 0.8$ & $2.6 \pm 0.9$ & $2.6 \pm 0.6$ & $3.4 \pm 1.2$ \\
\hline & $(\%)$ & 72 & $4.4 \pm 1.1^{\mathrm{c}}$ & $5.5 \pm 0.8^{\mathrm{b}, \mathrm{c}}$ & $6.4 \pm 0.9^{b}$ & $8.4 \pm 1.8^{\mathrm{a}}$ \\
\hline & $\left(\times 10^{6}\right)$ & & $3.2 \pm 1.0^{\mathrm{a}, \mathrm{b}}$ & $1.9 \pm 0.8^{b}$ & $3.2 \pm 0.8^{\mathrm{a}, \mathrm{b}}$ & $4.2 \pm 1.6^{\mathrm{a}}$ \\
\hline \multirow[t]{4}{*}{ CD19+ } & $(\%)$ & 24 & $59.3 \pm 4.3^{\mathrm{a}}$ & $30.1 \pm 9.7^{b}$ & $10.9 \pm 4.5^{\mathrm{c}}$ & $8.5 \pm 1.5^{\mathrm{c}}$ \\
\hline & $\left(\times 10^{6}\right)$ & & $40.4 \pm 5.6^{\mathrm{a}}$ & $14.0 \pm 9.6^{\mathrm{b}}$ & $4.0 \pm 2.1^{\mathrm{c}}$ & $3.6 \pm 1.7^{c}$ \\
\hline & $(\%)$ & 72 & $60.0 \pm 4.7^{\mathrm{a}}$ & $32.0 \pm 7.1^{\mathrm{b}}$ & $13.8 \pm 4.2^{\mathrm{c}}$ & $12.6 \pm 5.5^{\mathrm{c}}$ \\
\hline & $\left(\times 10^{6}\right)$ & & $42.9 \pm 4.5^{\mathrm{a}}$ & $11.3 \pm 4.9^{b}$ & $6.4 \pm 2.9^{b}$ & $6.6 \pm 4.1^{b}$ \\
\hline \multicolumn{2}{|l|}{ Index } & Hour & Control (PBS) & $\mathbf{C Y}+\mathbf{P B S}$ & $\begin{array}{c}\mathrm{CY}+\mathrm{BE} \\
10 \times 1 \mathrm{mg} / \mathrm{kg}\end{array}$ & $\begin{array}{c}\mathrm{CY}+\mathrm{BE} \\
10 \times 0.1 \mathrm{mg} / \mathrm{kg}\end{array}$ \\
\hline \multicolumn{7}{|c|}{ Splenocytes } \\
\hline \multirow[t]{4}{*}{ CD3+ } & $(\%)$ & 24 & $27.0 \pm 5.5^{\mathrm{c}}$ & $40.1 \pm 8.8^{b}$ & $53.7 \pm 5.1^{\mathrm{a}}$ & $53.1 \pm 5.3^{\mathrm{a}}$ \\
\hline & $\left(\times 10^{6}\right)$ & & $14.6 \pm 4.0$ & $13.3 \pm 4.2$ & $15.9 \pm 6.6$ & $20.4 \pm 3.9$ \\
\hline & $(\%)$ & 72 & $39.4 \pm 2.9^{c}$ & $49.4 \pm 4.7^{b}$ & $62.5 \pm 4.8^{\mathrm{a}}$ & $60.9 \pm 3.4^{\mathrm{a}}$ \\
\hline & $\left(\times 10^{6}\right)$ & & $24.4 \pm 4.2^{\mathrm{b}}$ & $23.5 \pm 6.3^{b}$ & $37.5 \pm 3.9^{\mathrm{a}}$ & $34.5 \pm 7.1^{\mathrm{a}}$ \\
\hline \multirow[t]{4}{*}{ CD4+ } & $(\%)$ & 24 & $22.8 \pm 5.4^{\mathrm{c}}$ & $32.9 \pm 7.6^{\mathrm{b}}$ & $52.3 \pm 6.3^{\mathrm{a}}$ & $52.1 \pm 5.1^{\mathrm{a}}$ \\
\hline & $\left(\times 10^{6}\right)$ & & $12.3 \pm 3.7^{b}$ & $10.9 \pm 3.4^{b}$ & $15.7 \pm 7.1^{\mathrm{a}, \mathrm{b}}$ & $20.0 \pm 3.6^{\mathrm{a}}$ \\
\hline & $(\%)$ & 72 & $31.1 \pm 2.7^{b}$ & $35.9 \pm 2.7^{b}$ & $43.3 \pm 5.2^{\mathrm{a}}$ & $44.1 \pm 3.2^{\mathrm{a}}$ \\
\hline & $\left(\times 10^{6}\right)$ & & $19.3 \pm 3.6^{\mathrm{b}, \mathrm{c}}$ & $17.1 \pm 4.5^{\mathrm{c}}$ & $25.9 \pm 2.9^{\mathrm{a}}$ & $25.1 \pm 5.5^{\mathrm{a}, \mathrm{b}}$ \\
\hline \multirow[t]{4}{*}{ CD8+ } & $(\%)$ & 24 & $4.2 \pm 1.4$ & $4.9 \pm 0.5$ & $5.4 \pm 1.0$ & $4.7 \pm 0.8$ \\
\hline & $\left(\times 10^{6}\right)$ & & $2.2 \pm 0.8$ & $1.7 \pm 0.6$ & $1.6 \pm 0.8$ & $1.8 \pm 0.3$ \\
\hline & $(\%)$ & 72 & $7.6 \pm 1.1$ & $9.6 \pm 2.1$ & $8.5 \pm 1.9$ & $8.3 \pm 1.5$ \\
\hline & $\left(\times 10^{6}\right)$ & & $4.7 \pm 0.9$ & $4.6 \pm 1.5$ & $5.1 \pm 1.3$ & $4.8 \pm 1.4$ \\
\hline \multirow[t]{4}{*}{ CD19+ } & $(\%)$ & 24 & $62.4 \pm 6.9^{\mathrm{a}}$ & $33.9 \pm 14.7^{b}$ & $16.1 \pm 4.6^{\mathrm{c}}$ & $11.1 \pm 3.0^{\mathrm{c}}$ \\
\hline & $\left(\times 10^{6}\right)$ & & $33.9 \pm 7.5^{\mathrm{a}}$ & $11.2 \pm 5.4^{\mathrm{b}}$ & $4.8 \pm 2.6^{\mathrm{b}}$ & $4.3 \pm 1.3^{\mathrm{b}}$ \\
\hline & $(\%)$ & 72 & $56.6 \pm 2.8^{\mathrm{a}}$ & $38.1 \pm 8.7 \mathrm{~b}$ & $18.9 \pm 6.0^{c}$ & $22.3 \pm 5.6^{c}$ \\
\hline & $\left(\times 10^{6}\right)$ & & $34.8 \pm 2.6^{\mathrm{a}}$ & $17.6 \pm 4.8^{b}$ & $11.4 \pm 4.0^{\mathrm{c}}$ & $12.3 \pm 2.6^{\mathrm{b}, \mathrm{c}}$ \\
\hline
\end{tabular}

Data with the different letter in the superscript show significant difference $(p<0.05)$ 
immunocorrecting effect on $\mathrm{T}$ lymphocytes of mesenteric lymph nodes after ten injections at a dose of $0.1 \mathrm{mg} / \mathrm{kg}$. This dosing schedule caused a significant increase in the percentage of CD3+ and CD4+ cells (increased by cyclophosphamide) and the absolute count of CD4+ lymphocytes in mesenteric lymph nodes (decreased by cyclophosphamide) on days 12 and 14 after immunosuppression. It also caused an increase in the absolute count of CD3+ lymphocytes (decreased by cyclophosphamide) on day 14 following the exposure to cyclophosphamide (Table 5). An increase in the percentage of CD3+ and CD4+ lymphocytes in mesenteric lymph nodes was observed after ten injections of bestatin at a dose of $1 \mathrm{mg} / \mathrm{kg}$ on days 12 and 14 after cyclophosphamide treatment. Moreover, an increase in the percentage of CD8+ and the absolute count of CD4+ T lymphocytes was noted on day 14 after injection of cyclophosphamide. Five exposures to bestatin exerted weaker immunocorrecting action on $\mathrm{T}$ lymphocytes in mesenteric lymph nodes. Bestatin administered five times at $48 \mathrm{~h}$ intervals at doses of 1 and $0.1 \mathrm{mg} / \mathrm{kg}$ increased the percentage of CD3+ and CD4+ lymphocytes in these organs (which was also increased by cyclophosphamide) (Table 5), but did not change the absolute count of these cells (which was decreased by cyclophosphamide). However, the percentage and the absolute count of CD8+ lymphocytes in mesenteric lymph nodes increased after administration of bestatin on alternating days at a dose of $0.1 \mathrm{mg} / \mathrm{kg}$.

\section{The effects of bestatin on the concentration of cytokines released by Th1/Th2 lymphocytes of cyclophosphamide - treated mice}

As can be seen in Table 6, a single injection of cyclophosphamide at a dose of $350 \mathrm{mg} / \mathrm{kg}$ significantly increased the serum concentrations of cytokines: IL-2, IL-5, IFN- $\gamma$, TNF- $\alpha$, released by Th1/Th2 lymphocytes, as determined on day 12 after drug injection.

Administration of bestatin decreased the concentrations of IL-2, IFN- $\gamma$ and TNF- $\alpha$ on day 12 after cyclophosphamide treatment. Irrespective of the dosage and number of subsequent doses applied, bestatin decreased the concentration of IL-2. A drop in serum IFN- $\gamma$ level was observed after five injections of bestatin at a dose of $1 \mathrm{mg} / \mathrm{kg}$ and after ten injections at both investigated doses. Simultaneously, the decrease in TNF- $\alpha$ was noted after five and ten exposures to bestatin at a dose of $0.1 \mathrm{mg} / \mathrm{kg}$. The similar trend was observed in case of IL-5, however the differences were not considered significant (Table 6).

\section{Discussion}

The results of the present study show that bestatin exerts the modulating effect on the total number of lymphocytes in the thymus, spleen and mesenteric lymph nodes in mice. Moreover, it was found that bestatin modifies the percentage and the absolute count of $\mathrm{T}$ cell subsets in the thymus and $\mathrm{T}$ and $\mathrm{B}$ lymphocytes in the spleen and mesenteric lymph nodes. The immunocorrecting action of bestatin on the total number of lymphocytes of lymphatic organs was observed only in splenocytes, after a dose of $1 \mathrm{mg} / \mathrm{kg}$ administered ten times at $24 \mathrm{~h}$ intervals, on day 14 after immunosuppression. It was also found that the immunocorrecting action of the drug on the percentage and the absolute count of subsets of $\mathrm{T}$ lymphocytes of lymphatic organs was dependent on the amount and number of subsequent doses applied. In the case of splenocytes, the strongest stimulating effect was observed after ten bestatin injections at all investigated doses, whereas in the case of the lymphocytes from mesenteric lymph nodes, it was observed at a dose of $0.1 \mathrm{mg} / \mathrm{kg}$. However, bestatin did not restore the percentage and the absolute count of B lymphocytes in spleen and mesenteric lymph nodes of cyclophosphamide-treated mice. What is more, the drug augmented the inhibitory action of cyclophosphamide on the percentage and the absolute count of B lymphocytes in these lymphatic organs.

The modulating effect of bestatin, in particular on T lymphocytes, was described by several authors. Kumano et al. [18] demonstrated the efficacy of bestatin in restoring the relative proportion of $\mathrm{T}$ cell subsets towards a normal balance in cancer patients. In these patients, bestatin administered orally at a daily dose of $30 \mathrm{mg}$ for 6 weeks decreased the percentage and the absolute count of suppressor/cytotoxic T cells (which had been pathologically increased), and raised the value of index CD4+/CD8+ (which had been reduced by the disease). Bestatin also increased the percentage and the absolute count of helper $\mathrm{T}$ cells and NK cells. However, the time of maximum response (2-, 4-, or 6-week) varied from one patient to another, for each parameter. Yamagishi et al. [6] found that oral administration of bestatin at a daily dose of $30 \mathrm{mg}$ for 1-2 months increased the absolute number of helper and cytotoxic T cells, expression of IL-2 receptor, PHA blastogenesis, PPD (purified protein derivative from tuberculosis) skin reaction, but decreased the absolute number of suppressor $\mathrm{T}$ cells in gastrointestinal cancer patients. The immunocorrecting action of bestatin on the subpopulations of lymphocytes in cancer patients was also observed by other authors [19]. Wakabayashi et al. [20] showed that in spite of having no influence on the overall number of precursor T cells, bestatin increased CD4+ and CD4+CD8+ cells and decreased CD8+ lymphocytes, which indicates that the drug induces the differentiation of precursor T cells into CD4+ lymphocytes.

Moreover, some studies indicate that bestatin has a mitogenic effect on lymphocytes [21,22], which is probably exerted through activation of macrophages. It is considered that bestatin either affects macrophages directly and these cells stimulate $\mathrm{T}$ lymphocyte proliferation, or the drug first activates the production of lymphokines by $\mathrm{T}$ cells thus stimulates macrophages indirectly. The latter mechanism 
Table 5. The percentage and absolute count of lymphocytes from mesenteric lymph node subpopulations in cyclophosphamide (CY)-treated mice after administration of bestatin (BE) five times on alternating days or ten times at $24 \mathrm{~h}$ intervals. The mean values $(n=8)$ and standard deviations are presented

\begin{tabular}{|c|c|c|c|c|c|c|}
\hline \multicolumn{2}{|l|}{ Index } & Hour & PBS & $\mathrm{CY}+\mathrm{PBS}$ & $\begin{array}{c}\mathrm{CY}+\mathrm{BE} \\
5 \times 1 \mathrm{mg} / \mathrm{kg} \\
\end{array}$ & $\begin{array}{c}\mathrm{CY}+\mathrm{BE} \\
5 \times 0.1 \mathrm{mg} / \mathrm{kg}\end{array}$ \\
\hline \multicolumn{7}{|c|}{ Mesenteric lymph node cells } \\
\hline \multirow[t]{4}{*}{ CD3+ } & $(\%)$ & 24 & $56.6 \pm 5.2^{c}$ & $81.7 \pm 5.8^{b}$ & $90.7 \pm 2.8^{\mathrm{a}}$ & $92.3 \pm 2.5^{\mathrm{a}}$ \\
\hline & $\left(\times 10^{6}\right)$ & & $18.6 \pm 1.9^{\mathrm{a}}$ & $10.9 \pm 5.6^{\mathrm{b}}$ & $13.9 \pm 7.0^{\mathrm{a}, \mathrm{b}}$ & $11.1 \pm 1.9^{\mathrm{b}}$ \\
\hline & $(\%)$ & 72 & $46.9 \pm 6.3^{c}$ & $79.3 \pm 9.5^{b}$ & $89.5 \pm 2.6^{\mathrm{a}}$ & $90.8 \pm 1.9^{\mathrm{a}}$ \\
\hline & $\left(\times 10^{6}\right)$ & & $13.8 \pm 3.5$ & $8.9 \pm 3.1$ & $9.9 \pm 4.1$ & $12.4 \pm 3.7$ \\
\hline \multirow[t]{4}{*}{ CD4+ } & $(\%)$ & 24 & $47.0 \pm 3.8^{c}$ & $64.8 \pm 6.5^{b}$ & $71.4 \pm 7.3^{\mathrm{a}, \mathrm{b}}$ & $74.1 \pm 3.7^{\mathrm{a}}$ \\
\hline & $\left(\times 10^{6}\right)$ & & $15.4 \pm 1.4^{\mathrm{a}}$ & $8.7 \pm 4.4^{b}$ & $11.0 \pm 5.6^{\mathrm{a}, \mathrm{b}}$ & $9.0 \pm 1.8^{\mathrm{b}}$ \\
\hline & $(\%)$ & 72 & $42.7 \pm 3.8^{c}$ & $60.1 \pm 8.0^{\mathrm{b}}$ & $70.6 \pm 5.7^{\mathrm{a}}$ & $65.5 \pm 4.7^{\mathrm{a}, \mathrm{b}}$ \\
\hline & $\left(\times 10^{6}\right)$ & & $12.6 \pm 2.9^{\mathrm{a}}$ & $6.7 \pm 2.4^{b}$ & $7.8 \pm 3.0^{\mathrm{b}}$ & $8.8 \pm 2.3^{\mathrm{a}, \mathrm{b}}$ \\
\hline \multirow[t]{4}{*}{ CD8+ } & $(\%)$ & 24 & $6.4 \pm 1.4^{\mathrm{c}}$ & $10.8 \pm 2.1^{\mathrm{b}}$ & $13.5 \pm 2.0^{\mathrm{a}, \mathrm{b}}$ & $16.3 \pm 2.6^{\mathrm{a}}$ \\
\hline & $\left(\times 10^{6}\right)$ & & $2.1 \pm 0.3$ & $1.4 \pm 0.6$ & $2.0 \pm 0.9$ & $2.0 \pm 0.4$ \\
\hline & $(\%)$ & 72 & $6.0 \pm 1.9^{\mathrm{d}}$ & $14.1 \pm 1.6^{\mathrm{b}, \mathrm{c}}$ & $14.7 \pm 5.0^{\mathrm{b}}$ & $20.0 \pm 2.6^{\mathrm{a}}$ \\
\hline & $\left(\times 10^{6}\right)$ & & $1.7 \pm 0.7^{\mathrm{a}, \mathrm{b}}$ & $1.5 \pm 0.4^{b}$ & $1.6 \pm 0.9^{\mathrm{a}, \mathrm{b}}$ & $2.7 \pm 0.9^{\mathrm{a}}$ \\
\hline \multirow[t]{4}{*}{ CD19+ } & $(\%)$ & 24 & $42.1 \pm 5.1^{\mathrm{a}}$ & $15.3 \pm 6.2^{b}$ & $3.4 \pm 2.1^{\mathrm{c}}$ & $1.6 \pm 0.4^{\mathrm{c}}$ \\
\hline & $\left(\times 10^{6}\right)$ & & $14.0 \pm 2.6^{\mathrm{a}}$ & $1.9 \pm 1.0^{\mathrm{b}}$ & $0.5 \pm 0.4^{b}$ & $0.2 \pm 0.1^{\mathrm{b}}$ \\
\hline & $(\%)$ & 72 & $50.8 \pm 6.5^{\mathrm{a}}$ & $13.1 \pm 5.3^{b}$ & $4.9 \pm 2.8^{\mathrm{c}}$ & $3.3 \pm 0.9^{c}$ \\
\hline & $\left(\times 10^{6}\right)$ & & $15.0 \pm 3.5^{\mathrm{a}}$ & $1.4 \pm 0.6^{\mathrm{b}}$ & $0.5 \pm 0.3^{\mathrm{b}}$ & $0.5 \pm 0.3^{b}$ \\
\hline \multicolumn{2}{|l|}{ Index } & Hour & Control (PBS) & $\mathbf{C Y}+\mathbf{P B S}$ & $\begin{array}{c}\mathrm{CY}+\mathrm{BE} \\
10 \times 1 \mathrm{mg} / \mathrm{kg}\end{array}$ & $\begin{array}{c}\mathrm{CY}+\mathrm{BE} \\
10 \times 0.1 \mathrm{mg} / \mathrm{kg}\end{array}$ \\
\hline \multicolumn{7}{|c|}{ Mesenteric lymph node cells } \\
\hline \multirow[t]{4}{*}{ CD3+ } & $(\%)$ & 24 & $55.8 \pm 5.4^{\mathrm{c}}$ & $73.0 \pm 10.3^{b}$ & $82.5 \pm 4.3^{\mathrm{a}}$ & $86.3 \pm 2.4^{\mathrm{a}}$ \\
\hline & $\left(\times 10^{6}\right)$ & & $18.0 \pm 4.8^{\mathrm{a}}$ & $11.0 \pm 4.9^{\mathrm{b}}$ & $14.7 \pm 4.7^{\mathrm{a}, \mathrm{b}}$ & $16.1 \pm 3.2^{\mathrm{a}, \mathrm{b}}$ \\
\hline & $(\%)$ & 72 & $53.8 \pm 4.9^{\mathrm{c}}$ & $74.7 \pm 4.7^{b}$ & $87.1 \pm 3.1^{\mathrm{a}}$ & $82.9 \pm 6.0^{\mathrm{a}}$ \\
\hline & $\left(\times 10^{6}\right)$ & & $18.7 \pm 2.4^{\mathrm{a}}$ & $10.7 \pm 4.0^{\mathrm{b}}$ & $16.4 \pm 3.8^{\mathrm{a}, \mathrm{b}}$ & $17.2 \pm 4.7^{\mathrm{a}}$ \\
\hline \multirow[t]{4}{*}{ CD4+ } & $(\%)$ & 24 & $43.8 \pm 4.2^{\mathrm{c}}$ & $58.8 \pm 9.5^{\mathrm{b}}$ & $71.9 \pm 5.5^{\mathrm{a}}$ & $78.1 \pm 3.6^{\mathrm{a}}$ \\
\hline & $\left(\times 10^{6}\right)$ & & $14.2 \pm 3.9^{\mathrm{a}, \mathrm{b}}$ & $8.7 \pm 3.7^{\mathrm{a}}$ & $12.7 \pm 3.6^{\mathrm{a}, \mathrm{b}}$ & $14.6 \pm 3.4^{b}$ \\
\hline & $(\%)$ & 72 & $45.9 \pm 3.2^{\mathrm{c}}$ & $62.5 \pm 2.7^{b}$ & $71.6 \pm 2.6^{\mathrm{a}}$ & $70.2 \pm 3.8^{a}$ \\
\hline & $\left(\times 10^{6}\right)$ & & $16.0 \pm 2.1^{\mathrm{a}}$ & $8.8 \pm 3.2^{\mathrm{b}}$ & $13.5 \pm 3.2^{\mathrm{a}}$ & $14.5 \pm 3.3^{\mathrm{a}}$ \\
\hline \multirow[t]{4}{*}{ CD8+ } & $(\%)$ & 24 & $8.7 \pm 3.6$ & $10.1 \pm 2.1$ & $12.1 \pm 3.4$ & $11.6 \pm 2.2$ \\
\hline & $\left(\times 10^{6}\right)$ & & $3.2 \pm 1.3^{\mathrm{a}}$ & $1.6 \pm 0.9^{\mathrm{b}}$ & $2.0 \pm 0.8^{\mathrm{a}, \mathrm{b}}$ & $2.1 \pm 0.4^{\mathrm{a}, \mathrm{b}}$ \\
\hline & $(\%)$ & 72 & $9.2 \pm 2.5^{\mathrm{b}}$ & $10.0 \pm 2.1^{\mathrm{b}}$ & $14.2 \pm 2.0^{\mathrm{a}}$ & $11.8 \pm 1.9^{\mathrm{a}, \mathrm{b}}$ \\
\hline & $\left(\times 10^{6}\right)$ & & $3.2 \pm 0.9^{\mathrm{a}}$ & $1.4 \pm 0.5^{\mathrm{b}}$ & $2.7 \pm 0.8^{\mathrm{a}, \mathrm{b}}$ & $2.5 \pm 0.9^{a, b}$ \\
\hline \multirow[t]{4}{*}{ CD19+ } & $(\%)$ & 24 & $39.8 \pm 5.5^{\mathrm{a}}$ & $21.2 \pm 10.7^{b}$ & $6.5 \pm 2.8^{\mathrm{c}}$ & $2.4 \pm 0.5^{\mathrm{c}}$ \\
\hline & $\left(\times 10^{6}\right)$ & & $12.7 \pm 2.9^{\mathrm{a}}$ & $3.6 \pm 1.4^{\mathrm{b}}$ & $1.3 \pm 0.6^{\mathrm{b}, \mathrm{c}}$ & $0.5 \pm 0.2^{c}$ \\
\hline & $(\%)$ & 72 & $45.0 \pm 5.1^{\mathrm{a}}$ & $22.4 \pm 5.6^{b}$ & $8.1 \pm 2.8^{c}$ & $5.8 \pm 3.3^{\mathrm{c}}$ \\
\hline & $\left(\times 10^{6}\right)$ & & $15.8 \pm 3.0^{\mathrm{a}}$ & $3.0 \pm 1.1^{\mathrm{b}}$ & $1.5 \pm 0.6^{\mathrm{b}}$ & $1.4 \pm 1.0^{\mathrm{b}}$ \\
\hline
\end{tabular}

Data with the different letter in the superscript show significant difference $(p<0.05)$ 
Table 6. The concentration of cytokines (IL-2, IL-5, IFN- $\gamma$, TNF- $\alpha$ ) released by Th1/Th2 lymphocytes in cyclophosphamide (CY)-treated mice after administration of bestatin (BE) five times on alternating days or ten times at $24 \mathrm{~h}$ intervals. The mean values $(n=8)$ and standard deviations are presented

\begin{tabular}{|c|c|c|c|c|}
\hline Group & IL-2 (pg/ml) & IL-5 (pg/ml) & IFN- $\gamma(\mathrm{pg} / \mathrm{ml})$ & TNF (pg/ml) \\
\hline Control (PBS) & $1.5 \pm 0.1^{\mathrm{c}}$ & $2.6 \pm 0.4^{b}$ & $3.0 \pm 1.4^{\mathrm{c}}$ & $8.4 \pm 3.6^{\mathrm{b}}$ \\
\hline $\mathrm{CY}(350 \mathrm{mg} / \mathrm{kg})+\mathrm{PBS}$ & $3.5 \pm 0.7 \mathrm{a}$ & $12.1 \pm 9.0^{\mathrm{a}}$ & $97.8 \pm 34.9^{\mathrm{a}}$ & $113.3 \pm 41.9^{\mathrm{a}}$ \\
\hline $\begin{array}{l}\mathrm{CY}+\mathrm{BE} \\
5 \times 1 \mathrm{mg} / \mathrm{kg}\end{array}$ & $2.3 \pm 0.5^{b, c}$ & $5.9 \pm 3.3^{\mathrm{a}, \mathrm{b}}$ & $35.3 \pm 16.4^{b, c}$ & $63.1 \pm 30.3^{\mathrm{a}, \mathrm{b}}$ \\
\hline $\begin{array}{l}\mathrm{CY}+\mathrm{BE} \\
5 \times 0.1 \mathrm{mg} / \mathrm{kg}\end{array}$ & $2.2 \pm 0.3^{\mathrm{b}, \mathrm{c}}$ & $4.7 \pm 1.8^{\mathrm{a}, \mathrm{b}}$ & $54.0 \pm 25.5^{\mathrm{a}, \mathrm{b}}$ & $44.0 \pm 10.6^{b}$ \\
\hline $\begin{array}{l}\mathrm{CY}+\mathrm{BE} \\
10 \times 1 \mathrm{mg} / \mathrm{kg}\end{array}$ & $2.5 \pm 0.4^{b}$ & $5.2 \pm 1.7^{\mathrm{a}, \mathrm{b}}$ & $36.3 \pm 8.5^{b, c}$ & $63.5 \pm 21.5^{\mathrm{a}, \mathrm{b}}$ \\
\hline $\begin{array}{l}\mathrm{CY}+\mathrm{BE} \\
10 \times 0.1 \mathrm{mg} / \mathrm{kg}\end{array}$ & $2.2 \pm 0.5^{\mathrm{b}, \mathrm{c}}$ & $4.5 \pm 2.8^{\mathrm{a}, \mathrm{b}}$ & $28.6 \pm 32.0^{\mathrm{b}, \mathrm{c}}$ & $52.4 \pm 40.4^{\mathrm{b}}$ \\
\hline
\end{tabular}

Data with the different letter in the superscript show significant difference $(p<0.05)$

would also lead to T cell proliferation [21]. However, it was proved that bestatin at a dose of $25 \mu \mathrm{g} / \mathrm{ml}$ did not restore the reduced mitogenic response of spleen cells in mice treated with cyclophosphamide [22].

Considering the results obtained in the present study and in other studies on immunomodulating action of bestatin on $\mathrm{T}$ lymphocytes, one may suppose that $\mathrm{T}$ lymphocyte is the cell on which bestatin exerts preferential stimulating effect. On the contrary, it is known that B lymphocyte is very susceptible to the suppressive action of cyclophosphamide [23], which is probably associated with a longer lifespan of B lymphocyte as compared with T cell [24]. Although cyclophosphamide suppresses $T$ cells [25] and macrophages [26] as well, this effect seems to be less pronounced as compared to B cells. Hemendinger and Bloom [27] observed a significant reduction in numbers of differentiating B lymphocytes and increase of apoptosis in these cells using the chicken embryo model system. On the other hand, T lymphocytes were much more resistant to the suppressive effect of cyclophosphamide. Misra and Bloom [28] reported that cyclophosphamide at doses of 50$100 \mathrm{mg} / \mathrm{kg}$ caused B cell depletion, whereas for T lymphocytes, this effect was reported at a dose of $200 \mathrm{mg} / \mathrm{kg}$. B cell mitosis was inhibited at the $5 \mathrm{mg} / \mathrm{kg}$ dose of immunosuppressant while a similar effect in the case of $\mathrm{T}$ cells was observed at a dose of $50 \mathrm{mg} / \mathrm{kg}$ of cyclophosphamide. Besides, the authors observed approximately two-fold higher levels of cyclophosphamide and its metabolites in bursal tissue in comparison with the thymus.

Therefore, it can be assumed that immunocorrecting action of bestatin on T lymphocytes of the thymus, spleen and mesenteric lymph nodes and a lack of this action on $\mathrm{B}$ lymphocytes, is due to the immunomodulating effect of bestatin on $\mathrm{T}$ cells and a strong suppressive action of cyclophosphamide on B lymphocytes. Besides, Morikawa et al. [29] showed that bestatin at a concentration range of 4-225 $\mu \mathrm{g} / \mathrm{ml}$ inhibited the proliferation and differentiation of human B cells in vitro. This effect was prevented by BCGF (B cell growth factor) or IL-2. The effect was not demonstrated in human B lymphoblastoid cell lines. The author suggested that bestatin may have bifunctional activities - stimulatory for $\mathrm{T}$ lymphocytes and inhibitory for B cells. Direct inhibitory influence of bestatin on B lymphocytes reported by Morikawa et al. [29] and preferential susceptibility of these cells to the suppressive action of cyclophosphamide may explain the results obtained in our study - further decrease in the percentage and the absolute count of B lymphocytes of spleen and mesenteric lymph nodes in bestatin-treated mice.

In the present study, we also investigated the action of bestatin on the secretory activity of Th1/Th2 lymphocytes in cyclophosphamide-treated mice. It was demonstrated that bestatin decreased the cyclophosphamide-induced release of IL-2, IFN- $\gamma$, and TNF- $\alpha$ from Th1/Th2 lymphocytes. Cyclophosphamide does not possess alkylating activity in vitro, but it is converted into two biologically active metabolites in the macroorganism. Bryniarski et al. [30] showed that incubation of murine peritoneal macrophages with these alkylating metabolites leads to an increase in the synthesis and release of IL-6 and IL-12, but it also causes a decrease in IL-10 and TGF- $\beta$ production by the cells. It is considered that the final action of cyclophosphamide metabolites on the cell activity depends on such factors as the concentration of the metabolites, time of exposure, actual cell metabolism, cell genetic equipment, and the model of the experiment (in vitro or in vivo) [30].

The action of bestatin on the cytokine production by lymphocytes was reported by many authors. Noma et al. [31] demonstrated that bestatin at a concentration range of $1-10 \mu \mathrm{g} / \mathrm{ml}$ increased the production of IL- 2 by PHA-stim- 
ulated human peripheral blood mononuclear cells. In ConAstimulated rat and mouse splenocytes, this effect was observed at even lower concentrations $(0.1-10 \mu \mathrm{g} / \mathrm{ml})$ [32]. However, Tsunogake et al. [33] found the activating effect of bestatin on the production of IL- 6 and TNF- $\alpha$ by nonstimulated peripheral blood mononuclear cells. The effect of bestatin on the production of murine interferon depends on many variables. In vitro studies have shown that the drug at a concentration of 1,10 and $100 \mu \mathrm{g} / \mathrm{ml}$ increased IFN synthesis in ConA-stimulated mouse T splenocytes, but no such effect was observed when cells were cultured without the mitogen. Bestatin administered 4 times at a dose of $1 \mathrm{mg} / \mathrm{kg}$ also increased the production of IFN, but only when mice were previously sensitized with BCG and administered with LPS on the day of the experiment. However, when bestatin was administered at a dose of $10 \mathrm{mg} / \mathrm{kg}$ and the mice received BCG instead of LPS, a decrease in the synthesis of IFN was observed.

The results obtained in our study are mostly in contradiction with those presented by other authors. The stimulatory action of bestatin on the production of cytokines was reported most frequently in mitogen-stimulated lymphocytes, whereas in our experiment, the effect of bestatin on the production of cytokines by Th1/Th2 lymphocytes was estimated in the unstimulated cells. Blomgren [34] demonstrated that incubation of human lymphocytes with bestatin but without mitogenic factors did not change the production of cytokines by these cells. In addition, lymphocytes used in our experiment were obtained not from normal, but from cyclophosphamide-treated animals. The methods used to measure the concentrations of cytokines also differed between the studies.

In the study concerning the influence of bestatin on the IFN production, Okura et al. [35] showed the relationship between the dose of $\mathrm{BCG}$ and the effect of this immunomodulator on the synthesis of IFN by lymphocytes. It was observed that sensitization of mice by BCG at doses of $10^{5}, 10^{6}$ increased the poli(I:C) - induced production of interferon, whereas the administration of higher doses $\left(10^{8}\right)$ decreased the synthesis of this cytokine. Therefore, it can be assumed that the above-mentioned differential effect of the compound on the production of cytokines depended on the initial status of the macroorganism. This may to some extent explain the results obtained in our study, which point to a reversal of cyclophosphamide-induced overproduction of IL- 2 , IFN- $\gamma$ and TNF- $\alpha$ by bestatin. What is more, Lkhagvaa et al. [36] reported the difference in action of bestatin on the production of cytokines by activated and unstimulated monocytes and macrophages. Bestatin at a concentration of 10 and $50 \mu \mathrm{g} / \mathrm{ml}$ inhibited the production of IL- 6 and IL- 8 by LPS-stimulated human monocytes. The effect was dose depended. Moreover, the drug at a higher concentration $-50 \mu \mathrm{g} / \mathrm{ml}$ - also suppressed the synthesis of MIP-1 $\alpha$ (macrophage inflammatory protein) but stimulated the release of IL-10. On the other hand, bestatin at a concentration of $10 \mu \mathrm{g} / \mathrm{ml}$ did not exert the effect on the production of IL- 6 by non-stimulated monocytes, whereas at a concentration of $50 \mu \mathrm{g} / \mathrm{ml}$, it even increased the release of that cytokine. Nevertheless, treatment with $50 \mu \mathrm{g} / \mathrm{ml}$ of bestatin suppressed the increased synthesis of IL-6 and IL-8 in alveolar macrophages in patients with sarcoidosis.

In conclusion, it can be stated that bestatin exerts a partial immunocorrective action on lymphocyte subsets in cyclophosphamide-treated mice. The substance also decreases the synthesis of IL- 2 , IFN- $\gamma$ and TNF- $\alpha$, whose overproduction is induced by cyclophosphamide. However, its action may vary, depending on the concentration of the drug and initial status of the cells.

This study was supported by the Polish State Committee for Scientific Research; Ministry of Science and Higher Education (Grant No 1889/PO1/2008/35).

\section{References}

1. Suda H, Takita T, Aoyagi T, Umezawa H (1976): The structure of bestatin. J Antibiot (Tokyo) 29: 100-101.

2. Mathé G (1991): Bestatin, an aminopeptidase inhibitor with a multi-pharmacological function. Biomed Pharmacother 45: 49-54.

3. Umezawa H, Aoyagi T, Suda H, et al. (1976): Bestatin, an inhibitor of aminopeptidase B produced by actinomycetes. J Antibiot (Tokyo) 29: 97-99.

4. Abe F, Schneider M, Black PL, Talmadge JE (1989): Chemoimmunotherapy with cyclophosphamide and bestatin in experimental metastasis in mice. Cancer Immunol Immunother 29: 231-236.

5. Schorlemmer HU, Bosslet K, Sedlacek HH (1983): Ability of the immunomodulating dipeptide bestatin to activate cytotoxic mononuclear phagocytes. Cancer Res 43: 4148-4153.

6. Yamagishi H, Naito K, Ueda Y, et al. (1991): Bestatin administration and the change in cellular immunity. Biomed Pharmacother 45: 117-120.

7. Sasaki S, Fukushima J, Hamajima K, et al. (1998): Adjuvant effect of Ubenimex on a DNA vaccine for HIV-1. Clin Exp Immunol 111: 30-35.

8. Harada Y, Kajiki A, Higuchi K, et al. (1983): The mode of immunopotentiating action of bestatin: enhanced resistance to Listeria monocytogenes infection. J Antibiot (Tokyo) 36: 14111414.

9. Aoyagi K, Itoh N, Abe F, et al. (1992): Enhancement by ubenimex (bestatin) of host resistance to Candida albicans infection. J Antibiot (Tokyo) 45: 1778-1784.

10. Lis M, Szczypka M, Suszko A, Obmińska-Mrukowicz B (2011): Influence of bestatin, an inhibitor of aminopeptidases, on $\mathrm{T}$ and B lymphocyte subsets in mice. Pol J Vet Sci 14: 393-403.

11. Lis M, Szczypka M, Suszko A, Obmińska-Mrukowicz B (2013): The effects of bestatin on humoral response to sheep erythrocytes in non-treated and cyclophosphamide-immunocompromised mice. Immunopharmacol Immunotoxicol 35: 133-138.

12. Bauvois B, Dauzonne D (2006): Aminopeptidase-N/CD13 (EC 3.4.11.2.) inhibitors: chemistry, biological evaluations and therapeutic prospects. Med Res Rev 26: 88-130. 
13. Luan Y, Xu W (2007): The structure and main functions of aminopeptidase N. Curr Med Chem 14: 639-647.

14. Aozuka Y, Koizumi K, Saitoh Y, et al. (2004): Anti-tumor angiogenesis effect of aminopeptidase inhibitor bestatin against B16-BL6 melanoma cells orthotopically implanted into syngeneic mice. Cancer Lett 216: 35-42.

15. Mishima Y, Terui Y, Sugimura N, et al. (2007): Continuous treatment of bestatin induces anti-angiogenic property in endothelial cells. Cancer Sci 98: 364-372.

16. Hirayama Y, Sakamaki S, Takayanagi N, et al. (2003): Chemotherapy with ubenimex corresponding to patient age and organ disorder for 18 cases of acute myelogeneous leukemia in elderly patients-effects, complications and longterm survival. Gan To Kagaku Ryoho 30: 1113-1118.

17. Urabe A, Mutoh Y, Mizoguchi H, et al. (1993): Ubenimex in the treatment of acute nonlymphocytic leukemia in adults. Ann Hematol 67: 63-66.

18. Kumano N, Suzuki S, Oizumi K, et al. (1985): Imbalance of T-cell subsets in cancer patients and its modification with bestatin, a small molecular immunomodifier. Tohoku J Exp Med 147: 125-133.

19. Tsukagoshi S (1987): A new antitumor drug with immunomodulating activity, ubenimex (bestatin). Gan To Kagaku Ryoho 14: 2385-2391.

20. Wakabayashi Y, Hashimoto M, Saitoh K, et al. (1991): Effects of bestatin (Ubenimex) on human T-cell colony formation. Anticancer Drugs 2: 39-43.

21. Ishizuka M, Sato J, Sugiyama Y, et al. (1980): Mitogenic effect of bestatin on lymphocytes. J Antibiot (Tokyo) 33: 653-662.

22. Dunlap BE, Dunlap SA, Rich DH (1984): Effect of bestatin on in vitro responses of murine lymphocytes to T-cell stimuli. Scand J Immunol 20: 237-245.

23. Willers JM, Sluis E (1975): The influence of cyclophosphamide on antibody formation in the mouse. Ann Immunol (Paris) 126: 267-279.

24. Fulcher DA, Basten A (1997): B cell life span: a review. Immunol Cell Biol 75: 446-455.

25. Mahiou J, Walter U, Lepault F, et al. (2001): In vivo blockade of the Fas-Fas ligand pathway inhibits cyclophosphamideinduced diabetes in NOD mice. J Autoimmun 16: 431-440.

26. Santosuosso M, Divangahi M, Zganiacz A, Xing Z (2002): Reduced tissue macrophage population in the lung by anticancer agent cyclophosphamide: restoration by local granulocyte macrophage-colony-stimulating factor gene transfer. Blood 99: 1246-1252.

27. Hemendinger RA, Bloom SE (1996): Selective mitomycin C and cyclophosphamide induction of apoptosis in differentiating B lymphocytes compared to T lymphocytes in vivo. Immunopharmacology 35: 71-82.

28. Misra RR, Bloom SE (1991): Roles of dosage pharmacokinetics and cellular sensitivity to damage in the selective toxicity of cyclophosphamide towards B and T cells in development. Toxicology 66: 239-256.

29. Morikawa K, Morikawa S, Nakano A, Oseko F (1989): Bestatin, an inhibitor of aminopeptidase B, suppresses the proliferation and differentiation of human B-cells in vitro. Int J Immunopharmacol 11: 905-913.

30. Bryniarski K, Szczepanik M, Ptak M, et al. (2009): Influence of cyclophosphamide and its metabolic products on the activity of peritoneal macrophages in mice. Pharmacol Rep 61: 550-557.

31. Noma T, Klein B, Cupissol D, et al. (1984): Increased sensitivity of IL2-dependent cultured T cells and enhancement of in vitro IL2 production by human lymphocytes treated with Bestatin. Int J Immunopharmacol 6: 87-92.

32. Shibuya K, Hayashi E, Abe F, et al. (1987): Enhancement of interleukin 1 and interleukin 2 releases by ubenimex. J Antibiot (Tokyo) 40: 363-369.

33. Tsunogake S, Furusawa A, Nagashima S, et al. (1994): Effect of aminopeptidase inhibitors on the production of various cytokines by peripheral blood mononuclear cells and stromal cells and on stem cell factor gene expression in stromal cells: comparison of ubenimex with its stereoisomers. Int J Immunotherapy 10: 41-47.

34. Blomgren H (1981): Bestatin, a new immunomodulator, augments the release of mitogenic factors from PHA-stimulated human lymphocytes. Biomedicine 34: 188-192.

35. Okura A, Ishizuka M, Takeuchi T, et al. (1988): Effect of ubenimex on the production of murine interferon. J Antibiot (Tokyo) 41: 261-263.

36. Lkhagvaa B, Tani K, Sato K, et al. (2008): Bestatin, an inhibitor for aminopeptidases, modulates the production of cytokines and chemokines by activated monocytes and macrophages. Cytokine 44: 386-391. 